\title{
Nutritional evaluation of sweet lupin (Lupinus angustifolius): net protein utilization (NPU), nitrogen balance and fractionation studies
}

\author{
BY MOHAMMED H. RAHMAN, IQBAL HOSSAIN AND MOSLEHUDDIN \\ Department of Pathology, Bangladesh Agricultural University, Mymensingh, Bangladesh
}

(Received 17 August 1995 - Revised 13 May 1996 - Accepted 7 June 1996)

\begin{abstract}
The effects of raw sweet lupin (Lupinus angustifolius) meal and its fractions on the growth and $\mathbf{N}$ utilization of rats were determined in two NPU and five $\mathbf{N}$ balance experiments. Sweet lupinseed grown in Western Australia, obtained as meal, unsupplemented (LMU), or fully supplemented with required amino acids $(360 \mathrm{~g} / \mathrm{kg}$ diet) (LMFS) was tested. In addition, six fractions were tested: aqueous non-dialysed extract at pH 7.0 (LPAND), dialysed extracts soluble (LPAD) and insoluble at pH 7.0 (LPADI), buffer-soluble extract at pH 7.0 (BUSOL), buffer-insoluble extract after dialysis at pH 7.0 (BUDI) and the residue (LMR) containing most of the material from meal insoluble in water and phosphate-citrate buffer. All diets based on fractions contained the same amounts of energy and protein and were supplemented with amino acids, vitamins and minerals to target requirements. Body $\mathrm{N}$ and lipid contents of rats fed on LMU and LMFS were reduced significantly in comparison with rats fed on positive lactalbumin (LACT) and non-protein diets (NPC) as negative controls. This was due in part to the lower retention of the absorbed N. As a result, the NPU and the biological value (BV) of sweet lupinseed proteins were less than expected. Urea-N outputs of the LMU- and LMFS-fed rats were also elevated. In contrast, true $N$ and DM digestibilities of rats fed on $L M U$ and LMFS were not significantly affected by the difference in the energy content of the diet. The replacement of lactalbumin in the diet with LPAND $(196 \mathrm{~g} / \mathrm{kg})$, LPAD $(148 \mathrm{~g} / \mathrm{kg})$, LPADI $(124 \mathrm{~g} / \mathrm{kg})$, BUSOL $(136 \mathrm{~g} / \mathrm{kg})$ or BUDI $(119 \mathrm{~g} / \mathrm{kg})$ reduced dry body weight, $\mathrm{N}$ and lipid contents, NPU and BV compared with those obtained from the LACT control, even though the $N$ and DM digestibilities were not significantly different. Inclusion of the residue fraction $(170 \mathrm{~g} \mathrm{LMR} / \mathrm{kg})$ had no apparent effect on any of the variables studied. Since sweet lupinseed had a small amount of nonreactive lectin and LMR had some undesirable side-effects in these rats, it appears that the low nutritional value of LMFS for rats (NPU 0.62) despite the very high level of digestibility of its $N$, results from disturbances in $\mathbf{N}$ metabolism, and particularly from the low retention value of the absorbed $\mathbf{N}$.
\end{abstract}

Lupinus angustifolius: Nutritional effects: Rats

Lupinus angustifolius (sweet lupin), a grain legume grown in Western Australia, is reported to contain negligible amounts of alkaloids and to be low in fat and anti-nutritive factors (Dagnia et al. 1992). The protein contents of different cultivars of this legume are higher than that of soyabean. As a result, it is being more widely used as a protein replacer in developed and developing countries. Recently, much information regarding its nutritive value after being incorporated into animal (Batterham, 1979; Murphy et al. 1993) and human (Egana et al. 1992) diets has emerged and since 1990, sweet lupins have gained acceptance in Australia for use in foods for humans (Evans et al. 1993). However, Batterham et al. (1986) observed that there was a low availability of lysine for growing pigs fed on a lupinseed-meal diet. It was therefore suggested that sweet lupinseed meal may 
contain an unidentified growth inhibitor(s) that depresses metabolism of amino acids, but not their digestion, as the ileal digestibility of lysine is high. Yen et al. (1989) observed from short-term feeding trials with growing rats, that there was a lack of support for growth when animals were fed on $L$. angustifolius seed meal fully supplemented with all essential amino acids to meet target requirements (Coates et al. 1969). However, little is known about the consequences for general metabolism of sweet lupinseed-meal fractions. Therefore, in the present investigation, six fractions were obtained from $L$. angustifolius by cold water and phosphate-citrate buffer extraction (McIlvaine, 1921) and tested in rats over a $10 \mathrm{~d}$ period for their dietary effects on body metabolism.

\section{MATERIALS AND METHODS}

\section{Materials}

Sweet lupinseed meal was obtained from the Grain Pool of Western Australia. Lactalbumin and all other dietary materials and reagents were purchased from BDH (Poole, Dorset) or Sigma Chemical Co. (Poole, Dorset). Maize oil was brought from Strachan and Sons (Aberdeen, Grampian). Trypsin, D-glucosamine, D-galactosamine, D-mannose, Dgalactose, $N$-acetyl galactosamine, $N$-acetyl glucosamine, L-fucose, fetuin, thyroglobulin, ovalbumin and ovomucoid were purchased from Sigma Chemical Co., St. Louis, MO, USA.

\section{Fractionation of the lupin meal}

Lupinseed meal was fractionated according to the scheme shown in Fig. 1 (Rahman, 1994). The seed meal was first extracted with cold water $(1: 10 \mathrm{w} / \mathrm{v})$ at $\mathrm{pH} 7.0$ and centrifuged $(48000 \mathrm{~g}, 30 \mathrm{~min})$. The supernatant fraction was freeze-dried and designated LPAND. In a second extraction the seed meal was extracted with water as previously described, the supernatant fraction was dialysed against distilled water, the $\mathrm{pH}$ adjusted to 7.0 and centrifuged as before. Two high-protein fractions were recovered after centrifugation of the dialysed material and freeze-dried; one soluble (fraction LPAD), and the other insoluble (fraction LPADI). The water-insoluble pellets were re-extracted with McIlvaine's buffer $(1: 8 \mathrm{w} / \mathrm{v}$ ) (phosphate-citrate, $0.2 \mathrm{M}: 0.1 \mathrm{M}$; Mcllvaine, 1921) at $\mathrm{pH} 7.0$, centrifuged, dialysed against water and the $\mathrm{pH}$ adjusted to $\mathrm{pH} 7.0$. Two high-protein fractions were recovered after centrifugation of the dialysed material and freeze-dried: one soluble at $\mathrm{pH}$ 7.0 (fraction BUSOL) and the other insoluble at $\mathrm{pH} 7.0$ (fraction BUDI). The final residue after extraction (fraction LMR) was dialysed against distilled water (Fig. 1) in a cold room $\left(4^{\circ}\right)$ and freeze-dried. Six fractions were obtained in all. The relative concentrations of the proteins expressed as a proportion of total crude protein $(N \times 5.5$; Mosse, 1990) in the flour $(278 \mathrm{~g} / \mathrm{kg})$ were as follows: LPAND 810, LPAD 475, LPADI 130, BUSOL 47, BUDI 5 and LMR $130 \mathrm{~g} / \mathrm{kg}$.

\section{Haemagglutination activity}

Blood samples were collected into pre-heparinized tubes and diluted with saline $(9 \mathrm{~g}$ $\mathrm{NaCl} / 1$ ) after collection. Erythrocytes of rabbits, rats and hamsters were pre-treated with trypsin $\left(0.1 \mathrm{mg} / 20 \mathrm{ml}\right.$ diluted erythrocytes for $30 \mathrm{~min}$ at $25^{\circ}$; Grant et al. 1983). Dialysed lupinseed-meal extract at pH 7.0, and the freeze-dried fractions (LPAD, LPADI and LMR) dissolved in $5 \mathrm{mg} / \mathrm{ml}$ phosphate-buffered saline (PBS), were tested for haemagglutinating properties. Each fraction was serially diluted using an automatic pipetting device and 


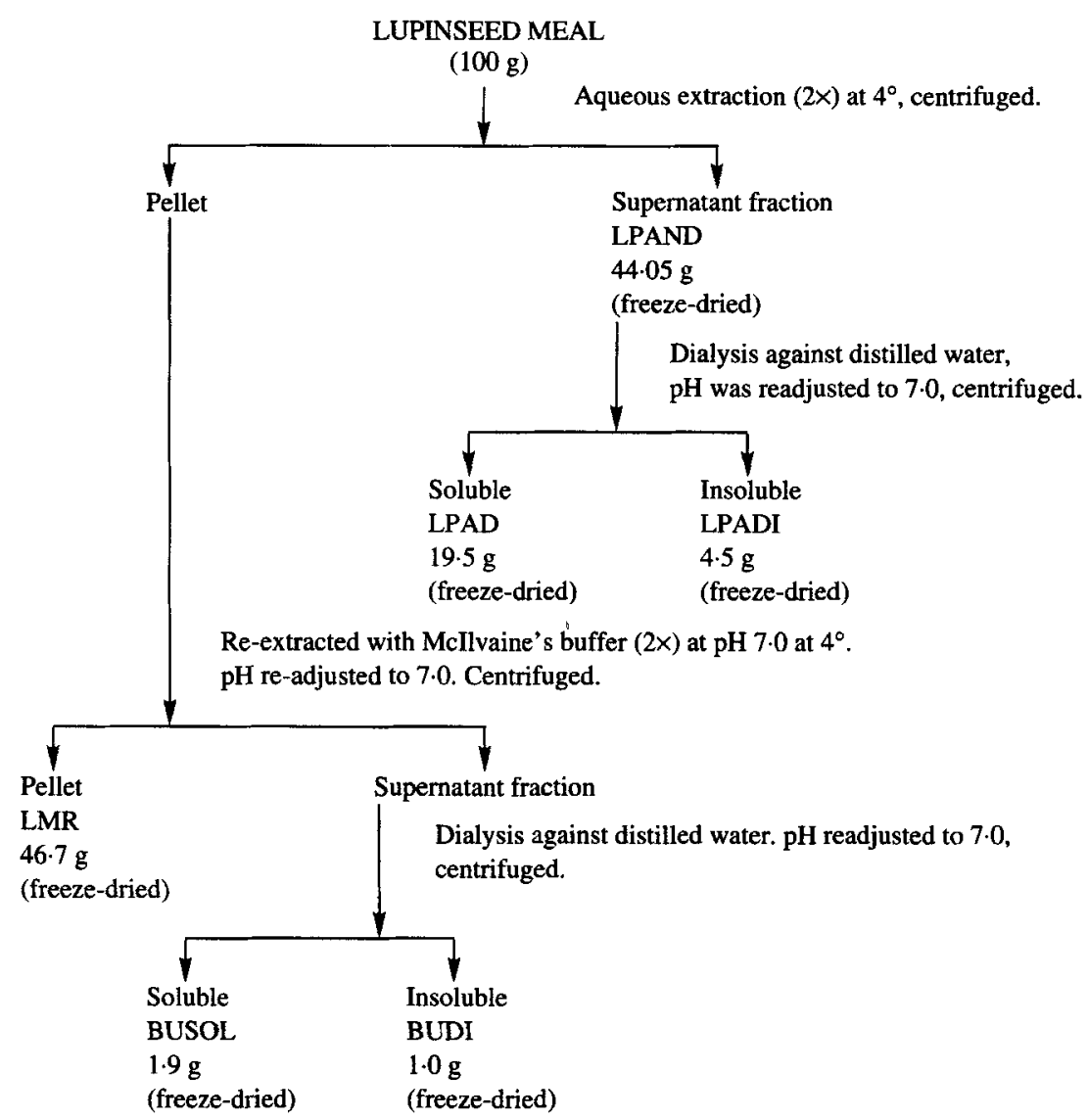

Fig. 1. Scheme for the extraction of different fractions from Lupinus angustifolius-seed meal.

mixed with equal volumes of diluted erythrocytes (final volume $0.1 \mathrm{ml}$ ). This gave the following sample concentration $(\mu \mathrm{g} / \mathrm{ml})$ in the haemagglutinating assay:

$\begin{array}{llllllllllll}\text { Tube no. } & 1 & 2 & 3 & 4 & 5 & 6 & 7 & 8 & 9 & 10 & 12 \\ \text { Conc. } & 1250 & 625 & 312 & 156 & 78 & 39 & 19.5 & 9.8 & 4.9 & 2.4 & 0.6\end{array}$

The mixed samples were left for $16 \mathrm{~h}$ and then the amount of clumping was assessed by microscope. Kidney bean (Phaseolus vulgaris var. Processor) lectin (Pusztai et al. 1979) and arcelin 2, a lectin-like protein (Pusztai, 1991) were included in each assay as standard controls. One unit of haemagglutination activity $(\mathrm{HU})$ was defined as the amount of material $/ \mathrm{ml}$ in the last dilution giving $50 \%\left(2^{+}\right)$agglutination. For comparative purposes, the activity of the various samples was given as the amount of material $(\mu \mathrm{g})$ containing $1 \mathrm{HU}$. The limits of experimental accuracy for this technique are \pm 1 dilution and therefore samples with a titre of 625 will have a range of accuracy of 1250-312. Therefore, the threshold values of $1250,620,310,160,80,40 \ldots \mu \mathrm{g} / \mathrm{ml}$ were chosen. Although the results for multiple samples were combined to produce an arithmetic mean, because of the experimental error and for comparative purposes, any value which was not equivalent to one of the sample threshold concentrations used, was rounded up to the nearest actual value. For example, the average of 1250 and 625 was given as 1250 . 


\section{Haemagglutination inhibition assay}

This test was carried out in the same way as the haemagglutination tests. However only the LPAD fraction was tested, since it showed the highest level of haemagglutination activity. The sample $(5 \mathrm{mg} / \mathrm{ml}$ in PBS) was serially diluted with normal saline. Under such conditions, $714 \mu \mathrm{g} / \mathrm{ml}$ of this preparation gave a definite clumping of trypsinized hamster erythrocytes. Each potential inhibitor (simple sugars and their derivatives as well as glycoproteins) was serially diluted with saline which also contained the haemagglutinin samples at the given concentration $(714 \mu \mathrm{g} / \mathrm{ml})$. Starting concentrations were $25 \mathrm{mg} / \mathrm{ml}$ for sugars and $2.5 \mathrm{mg} / \mathrm{ml}$ for glycoproteins. After addition of trypsinized hamster cells (final volume $0.2 \mathrm{ml}$ ), the tubes were incubated at room temperature for $3 \mathrm{~h}$ before reading. Inhibitory efficacy was compared on the basis of $50 \%\left(2^{+}\right)$inhibition.

\section{Diets}

Details of the ingredients used to prepare diets are shown in Table 1. Raw seed meal (crude protein content $(\mathrm{N} \times 5.5) 278 \mathrm{~g} / \mathrm{kg})$ and its fractions were used as the source of protein in diets to supply a level of $100 \mathrm{~g}$ protein $/ \mathrm{kg}$. The diet that contained LMR (residue fraction) has to be supplemented with lactalbumin to reach $100 \mathrm{~g} / \mathrm{kg}$ final protein concentration. Thus, the LMR accounted for only $13.9 \mathrm{~g}$ of the total protein in the diet. Diets containing $100 \mathrm{~g}$ total protein $/ \mathrm{kg}$ and $150 \mathrm{~g}$ oil $/ \mathrm{kg}$ with a gross energy content of $17 \mathrm{~kJ} / \mathrm{g}$ were formulated as described earlier (Rahman et al. 1996a) in the first NPU feeding experiment. However, the level of oil was increased to $186 \mathrm{~g} / \mathrm{kg}$ in the second experiment and this was used in all subsequent feeding trials. Seed-meal fractions and lactalbumin were subjected to detailed amino acid analysis before being used for this experiment. All diets except that containing unsupplemented lupinseed meal (LMU) had to be supplemented with essential amino acids to reach the target requirements (Coates et al. 1969). A protein-free diet (NPC) was used as a negative control. The residue fraction (LMR) which comprised $467 \mathrm{~g} / \mathrm{kg}$ whole meal (on an air-dry basis) was included in diets in the same proportion as that in the meal.

\section{Animals}

Male Hooded-Lister rats (Rowett colony), reared and housed under standard conditions in the Small Animal Unit of the Rowett Research Institute, were weaned at $19 \mathrm{~d}$ and kept on a standard stock diet (Special Diet Services, Manea, Cambs.) in individual cages for $10 \mathrm{~d}$. They were then pre-fed ad libitum on the lactalbumin control diet (LACT; Table 1) for 3$4 \mathrm{~d}$ before the start of the experiment. Water was available ad libitum at all times.

\section{Nutritional studies (restricted intake experiments)}

NPU, N digestibility, and biological value (BV) were determined using a method based on that described by Miller \& Bender (1955) and modified by Palmer et al. (1973). Rats weighing $80-85 \mathrm{~g}$ were housed individually, and fed on the appropriate test or control diet at $7 \mathrm{~g} / \mathrm{d}$ per rat for $10 \mathrm{~d}$. A total of sixty rats (four rats/treatment) were used in two feeding trials. All rats were strictly pair-fed and were restricted to $7.0 \mathrm{~g} /$ rat per $d$ feed intake. The dietary treatments for the NPU trial were: NPC, LACT, LMU, LMFS, LPAND, LPAD, LPADI, BUSOL, BUDI and LMR. Faecal samples were collected daily between days 4 and 10. At the end of the experiment, rats were killed by diethyl ether anaesthesia overdose. The carcass and faecal samples were freeze-dried and ground in a Moulinex coffee grinder. 
Table 1. Composition of diets $(\mathrm{g} / \mathrm{kg})$ used for net protein utilization and nitrogen balance trials*

\begin{tabular}{|c|c|c|c|c|c|c|c|c|c|c|}
\hline Dietary group... & NPC & LACT & LMU & LMFS & LPAND & LPAD & LPADI & BUSOL & BUDI & LMR \\
\hline Maize starch & 500 & 370 & 104 & 104 & 304 & 352.6 & 376 & 364 & 381 & 220 \\
\hline Potato starch & 100 & 100 & 100 & 100 & 100 & 100 & 100 & 100 & 100 & 100 \\
\hline Glucose & 150 & 150 & 150 & 150 & 150 & 150 & 150 & 150 & 150 & 150 \\
\hline Maize oil & 150 & 150 & 186 & 186 & 150 & 150 & 150 & 150 & 150 & 150 \\
\hline Minerals $\dagger$ & 50 & 50 & 50 & 50 & 50 & 50 & 50 & so & 50 & 50 \\
\hline Vitamins $\dagger$ & 50 & 50 & 50 & 50 & 50 & 50 & 50 & 50 & 50 & 50 \\
\hline $\begin{array}{l}\text { Lactalbumin } \\
\quad(770 \text { g protein } / \mathrm{kg}) \ddagger\end{array}$ & - & 130 & - & - & - & - & - & - & - & 112 \\
\hline $\begin{array}{l}\text { Lupinseed meal } \\
(50.5 \mathrm{~g} \mathrm{~N} / \mathrm{kg}, 278 \mathrm{~g} \\
\text { protein } / \mathrm{kg}) \S\end{array}$ & - & - & 360 & 360 & - & - & - & - & - & - \\
\hline $\begin{array}{l}\text { LPAND } \\
\quad(92.7 \mathrm{~g} \mathrm{~N} / \mathrm{kg}, 510 \mathrm{~g} \\
\text { protein } / \mathrm{kg}) \S\end{array}$ & - & - & - & - & 196 & - & - & - & - & - \\
\hline $\begin{array}{l}\text { LPAD } \\
\qquad \begin{array}{l}(123 \cdot 1 \mathrm{~g} \mathrm{~N} / \mathrm{kg}, 677 \mathrm{~g} \\
\text { protein } / \mathrm{kg}) \S\end{array}\end{array}$ & - & - & - & - & - & 148 & - & - & - & - \\
\hline $\begin{array}{l}\text { LPADI } \\
\qquad(147 \mathrm{~g} \mathrm{~N} / \mathrm{kg}, 809 \mathrm{~g} \\
\text { protein } / \mathrm{kg}) \S\end{array}$ & - & - & - & - & - & - & 124 & - & - & - \\
\hline $\begin{array}{l}\text { BUSOL } \\
\begin{array}{l}(134 \mathrm{~g} \mathrm{~N} / \mathrm{kg}, 737 \mathrm{~g} \\
\text { protein } / \mathrm{kg}) \S\end{array}\end{array}$ & - & - & - & - & - & - & - & 136 & - & - \\
\hline $\begin{array}{l}\text { BUDI } \\
\begin{array}{l}(152.5 \mathrm{~g} \mathrm{~N} / \mathrm{kg}, 839 \mathrm{~g} \\
\text { protein } / \mathrm{kg}) \S\end{array}\end{array}$ & - & - & - & - & - & - & - & - & 119 & - \\
\hline LMR & - & - & - & - & - & - & - & - & - & 170 \\
\hline Amino acids $\|$ & & & & & & & & & & \\
\hline Threonine & - & - & - & - & 0.54 & 0.14 & 0.7 & - & 0.13 & - \\
\hline Lysine & - & - & - & 0.23 & 2.0 & 0.7 & 0.9 & 0.8 & 1.9 & - \\
\hline Leucine & - & - & - & 0.4 & 1.26 & 1.5 & - & - & 1.7 & - \\
\hline Tryptophan & - & - & - & 0.4 & 1.23 & 0.4 & 1.4 & 0.46 & 1.3 & 0.09 \\
\hline Tyrosine & - & - & - & - & 0.11 & - & - & - & 3.2 & - \\
\hline Phenylalanine & - & - & - & 0.57 & $1 \cdot 14$ & 1.6 & 0.9 & 0.17 & 0.4 & - \\
\hline Isoleucine & - & - & - & 1.26 & 1.26 & 1.3 & 0.2 & - & 1.26 & 0.11 \\
\hline Valine & - & - & - & 1.54 & 2.0 & 1.0 & 1.3 & 0.29 & 0.2 & 0.06 \\
\hline Methionine & - & - & - & $2 \cdot 17$ & 2.37 & $2 \cdot 2$ & 2.4 & 1.0 & $1 \cdot 2$ & 0.2 \\
\hline Silicic acid & 0.4 & 0.4 & 0.4 & 0.4 & 0.4 & 0.4 & 0.4 & 0.4 & 0.4 & 0.4 \\
\hline Gross energy $(\mathrm{kJ} / \mathrm{g})$ ๆ & 16.3 & 17.8 & $20 \cdot 0$ & $20 \cdot 0$ & ND & 18.6 & 18.9 & $18 \cdot 1$ & 18.8 & $20 \cdot 0$ \\
\hline $\begin{array}{l}\text { Metabolizable energy } \\
(\mathrm{kJ} / \mathrm{g}) \uparrow\end{array}$ & ND & 16.8 & $16 \cdot 4$ & 16.4 & ND & 16.7 & 16.8 & 16.8 & 16.8 & 16.8 \\
\hline Crude protein $(\mathrm{g} / \mathrm{kg})$ & 0.4 & 100 & 100 & 100 & 100 & 100 & 100 & 99.1 & 100 & 100 \\
\hline
\end{tabular}

LACT, lactalbumin protein control diet; ND, not determined; NPC, non-protein diet.

* For details of abbreviations and the fractionation procedure, see Fig. 1 and p. 444.

$\dagger$ For details of minerals and vitamins used, see Rahman et al. (1996b).

$\pm N \times 6.25$.

$\S \mathrm{N} \times 5.5$.

I| Amino acid levels were brought up to target requirements for rats (Coates et al. 1969) for all diets except NPC and LACT. All amino acids incorporated were of the L-configuration.

Energy levels were calculated on the basis of $16.5 \mathrm{~kJ} / \mathrm{g}$ carbohydrate and protein, and $39.5 \mathrm{~kJ} / \mathrm{g}$ fat.

\section{Nutritional studies (nitrogen balance experiments)}

Male Hooded-Lister (Rowett strain) rats were used for the experiments. They were weaned at $19 \mathrm{~d}$, fed on non-purified stock diet (Labsure, Manea, Cambs.) for $10 \mathrm{~d}$ and then fed on 
semi-purified lactalbumin control diet (LACT) for a further 5-6 d. After the rats had reached $80-85 \mathrm{~g}$ in weight they were given the appropriate test or control diets exclusively for $10 \mathrm{~d}$. A total of 135 rats (four rats/treatment) were used in five $\mathrm{N}$ - balance feeding trials. All rats were strictly pair-fed and were restricted to $7.0 \mathrm{~g} / \mathrm{rat}$ per $\mathrm{d}$ feed intake. The dietary treatments for five $\mathrm{N}$ balance trials were: NPC, LACT, LMU, LMFS, LPAND, LPAD, LPADI, BUSOL, BUDI and LMR. The method used was based on that described by Miller \& Bender (1955) and modified by a procedure essentially based on Pusztai et al. (1981). The treatments, imposed in five runs, were:

run (a), treatments NPC, LACT, LMU and LMFS;

run (b), treatments NPC, LACT, LMU and LMFS;

run (c), treatments LACT, LMU, LMFS, LPAND, and LMR;

run (d), treatments LACT, LMU, LMFS, BUSOL and BUDI (two replicates);

run (e), treatments LACT, LMFS, BUSOL, BUDI, LPAD, LPADI and LMR.

Water was freely available at all times. The animals were weighed daily. Urine samples were collected in $5.0 \mathrm{ml}$ sulphosalicylic acid (120 g/l) and faecal samples were collected daily. For analysis, two $1 \mathrm{~d}$ collections were pooled (giving five samples of faeces and urine in $10 \mathrm{~d}$ ) and stored at $-20^{\circ}$ until required. Faeces samples were freeze-dried, ground in a mortar and stored in a dry place until analysed.

At the end of each experimental run, rats were killed by ether anaesthesia overdose. The stomach, small intestine, caecum and colon were removed and their contents washed out with copious amounts of ice-cold $0.05 \mathrm{M}$-PBS. The tissues were blotted dry, visually examined for the presence of any macroscopic lesions, and then frozen on solid $\mathrm{CO}_{2}$. The liver, kidneys, adrenals, pancreas, spleen, thymus, lungs, heart and the soleus, plantaris and gastrocnemius hind-limb muscles were excised, washed with PBS, blotted dry, examined, and frozen on solid $\mathrm{CO}_{2}$. All the tissues and remaining carcass were weighed, freeze-dried, reweighed, recombined and ground with a mincer for chemical analyses.

\section{Analytical methods}

Protein and lipid. Diets, lupinseed, meal, fractions, faeces, urines and carcasses were analysed for total $N$ (Davidson et al. 1970). Body protein was calculated as $\mathrm{N} \times 6.25$ and diet protein as $\mathbf{N} \times 5 \cdot 5$. Estimation of total lipid was done after extraction of the ground tissue with chloroform-methanol $(2: 1, \mathrm{v} / \mathrm{v})$ at a sample: solvent ratio of $1: 200, \mathrm{w} / \mathrm{v}$ (Grant et al. 1983). Urine samples were analysed for urea using a standard Technicon Analyser method.

Carbohydrates. The total carbohydrate content of seed meal and fractions as monosaccharide components was analysed using the procedure of Englyst \& Cummings (1984). The carbohydrate compositions of the seeds and seed fractions were also determined. The amounts of free sugars were assayed by HPLC after extraction with boiling ethanol solution $(800 \mathrm{ml} / \mathrm{l})$, and the starch content was measured as described by Åman \& Hessleman (1984). NSP were determined by the method of Englyst \& Cummings (1984). Samples were treated with dimethylsulphoxide to solubilize starch, which was then hydrolysed with $\alpha$-amylase ( $E C$ 3.2.1.1), pullulanase (EC 3.2.1.41) and pancreatin. The NSP were precipitated by ethanol $(800 \mathrm{ml} / \mathrm{l})$, separated from the supernatant fraction by centrifugation, dispersed in $12 \mathrm{M}_{2} \mathrm{H}_{2} \mathrm{SO}_{4}$, which was then diluted to $1 \mathrm{M}$, and hydrolysed. The constituent sugars were estimated by GLC as their alditol acetate derivatives. Uronic acids were determined colorimetrically. 
Gross energy. Gross energy content of the diet was estimated by adiabatic bomb calorimetry.

Amino acid analysis. Seed meal and fractions were analysed for amino acids (Moore $e t$ al. 1958) and S-containing amino acids (Moore, 1963).

SDS-polyacrylamide gel electrophoresis (SDS-PAGE). SDS-PAGE was carried out on seed meal and each fraction before it was incorporated into the diet, to test for homogeneity in fractionation, using the procedure of Laemmli (1970).

\section{Calculations}

NPU, N digestibility and BV were calculated for each dietary treatment group (Miller \& Bender, 1955; Palmer et al. 1973), from the formulas:

$$
\mathrm{NPU}=\frac{\mathrm{B}-\mathrm{Bk}+\mathbf{I k}}{\mathrm{I}},
$$

where $\mathrm{B}$ is the total carcass $\mathrm{N}$ of the positive control of experimental groups, Bk is the total carcass $\mathrm{N}$ of the negative control (rats fed on protein-free diet) group, $\mathrm{I}$ is the $\mathrm{N}$ intake of the positive control or experimental groups, and Ik is the $\mathrm{N}$ intake of the negative control group.

$$
\text { True } \mathrm{N} \text { digestibility }(\mathrm{TD})=\frac{\mathrm{N}-\mathrm{Fn}+\mathrm{Fnk}}{\mathrm{N}},
$$

where $\mathrm{N}$ is the $\mathrm{N}$ contained in $100 \mathrm{~g}$ experimental diet $(\mathrm{g})$, Fn is the faecal $\mathrm{N}$ derived from $100 \mathrm{~g}$ experimental diet $(\mathrm{g})$, and Fnk is the faecal $\mathrm{N}$ derived from non-protein control diet (g).

$$
\mathrm{BV}=\frac{\mathrm{NPU} \times 100}{\mathrm{DIG}},
$$

where DIG is digestibility.

$\mathrm{N}$ balance (apparent $\mathrm{N}$ retention) $=\mathrm{I}-\mathrm{F}-\mathrm{U}$,

where $\mathrm{I}$ is intake, $\mathrm{F}$ is faecal $\mathrm{N}$ excretion and $\mathrm{U}$ is urinary $\mathrm{N}$ excretion.

$\mathrm{N}$ balance data were obtained by measuring dietary $\mathrm{N}$ intake and urinary and faecal $\mathrm{N}$ output by direct analysis. Correction for endogenous $\mathrm{N}$ loss was not made.

\section{Statistical analysis}

Results of the five replicates of the $\mathrm{N}$ balance experiment were pooled and statistical analysis was done by one-way ANOVA using the Minitab computer program (Minitab Inc., State College, PA 16801, USA). When $P$ values were $<0.05$, the significance of difference between groups was estimated by Student's $t$ test.

\section{RESULTS}

Lupin protein was found to be almost completely extractable at neutral $\mathrm{pH}(7.0)$ leaving a residue fraction (LMR) depleted of proteins (Table 2). As shown in Table 3, seed meal contained little starch while the insoluble carbohydrate fraction remaining after protein extraction (LMR) contained a large amount of insoluble NSP. The results of the tests of haemagglutination and its inhibition by sugars and/or glycoproteins for lupin-seed extract and its fractions are given in Tables 4 and 5. Haemagglutinating activity was observed with trypsinized rat and hamster erythrocytes but not rabbit erythrocytes. Compared with lectin 
obtained from Phaseolus vulgaris and arcelin-like lectin, lupin lectin was 1875 and 4 times less active. Background clumping with trypsin-treated rat erythrocytes was high, but consistent results and a clear background were obtained from trypsin-treated hamster erythrocytes. Therefore, the use of rat erythrocytes was discontinued. Haemagglutination by LPAD could not be inhibited by $N$-acetyl glucosamine, $N$-acetyl galactosamine, Lfucose, D-mannose or D-galactose at the highest concentration used $(25 \mathrm{mg} / \mathrm{ml})$ (Table 5). Of the glycoproteins tested, thyroglobulin was the most effective inhibitor, although fetuin and ovomucoid were also potentially active. Ovalbumin was not inhibitory even at the highest concentration used $(2.5 \mathrm{mg} / \mathrm{ml})$. These results indicate that lupin seeds contain small amounts of a lectin with complex sugar (glycoprotein) specificity.

The amino acid composition of the seed meal and its fractions and lactalbumin are presented in Table 2. The seed meal was deficient in several essential amino acids including methionine, tryptophan, isoleucine, valine, phenylalanine, lysine and threonine. The residue (LMR) however, was not deficient in threonine. The most abundant amino acids in the seed meal and fractions were glutamic acid, aspartic acid and arginine. In addition, the concentrations of isoleucine, valine and leucine in the meal and the fractions were lower than that needed to satisfy the target requirements. Important differences were found in the half cystine:methionine ratio in the seed meal and its fractions. The

Table 2. Nitrogen, total protein and amino acid composition of lactalbumin (LACT), Lupinus angustifolius-seed meal flour and its fractions*

\begin{tabular}{|c|c|c|c|c|c|c|c|c|c|}
\hline & LACT & $\begin{array}{l}\text { Lupinseed } \\
\text { meal (LM) }\end{array}$ & LPAND & LPAD & LPADI & BUSOL & BUDI & LMR & Target $\% \S$ \\
\hline Weight (g) & 100 & 100 & $44 \cdot 1$ & $19 \cdot 6$ & $4 \cdot 5$ & 1.9 & 1.0 & $46 \cdot 7$ & \\
\hline $\mathbf{N}(\%)$ & $12 \cdot 3$ & 5.05 & 9.3 & 12.3 & 14.7 & 13.4 & $15 \cdot 2$ & 1.4 & \\
\hline Crude protein $(\mathrm{g}) \dagger$ & 77 & 27.8 & $22 \cdot 5$ & $13 \cdot 2$ & 3.6 & $1 \cdot 3$ & 0.15 & 3.6 & \\
\hline \multicolumn{10}{|c|}{ Amino acids $(\mathrm{g} / 16 \mathrm{~g} \mathrm{~N}) \ddagger$} \\
\hline Asp & 9.0 & 11.6 & $7 \cdot 7$ & 9.4 & 11.9 & $5 \cdot 5$ & 6.6 & 10.4 & \\
\hline Thr & 4.9 & 3.7 & 2.9 & 3.9 & 3.3 & 4.3 & $3 \cdot 8$ & $5 \cdot 1$ & 4.0 \\
\hline Ser & $4-0$ & $5 \cdot 0$ & $4 \cdot 1$ & 4.5 & $5 \cdot 3$ & 4.4 & 5.7 & $5 \cdot 1$ & \\
\hline Glu & $14 \cdot 8$ & 20.9 & 25.4 & $24 \cdot 0$ & 27.6 & 18.9 & $16 \cdot 3$ & 12.9 & \\
\hline Gly & 2.1 & $4 \cdot 1$ & 3.7 & 4.4 & $4 \cdot 3$ & $4 \cdot 3$ & 3.8 & 4.9 & \\
\hline Ala & 5.4 & 3.6 & 2.9 & 3.9 & 3.2 & 4.2 & 3.2 & 4.4 & \\
\hline Val & 5.9 & 3.5 & 3.0 & 3.9 & 3.7 & 3.8 & 4.4 & 5.0 & 5.0 \\
\hline Ile & $5 \cdot 8$ & $3 \cdot 3$ & 3.2 & 3.7 & 4.8 & 4.1 & 4.2 & 3.9 & 5.0 \\
\hline Leu & 9.5 & 6.7 & 5.7 & 6.5 & 8.1 & $6 \cdot 2$ & 8.4 & 7.7 & 8.0 \\
\hline Tyr & 1.5 & 3.8 & 3.4 & 3.4 & 3.7 & 3.6 & 4.0 & 4.5 & \\
\hline Phe & 5.6 & 3.9 & 3.4 & 3.4 & $4 \cdot 1$ & 3.6 & 4.6 & 4.8 & 5.0 \\
\hline His & 2.9 & 2.6 & 2.2 & 2.3 & 2.6 & $2 \cdot 1$ & 3.4 & $3 \cdot 5$ & $2 \cdot 5$ \\
\hline Lys & 8.9 & 5.1 & 3.4 & $5 \cdot 4$ & 4.6 & 5.1 & $4 \cdot 1$ & 5.9 & 6.0 \\
\hline Arg & 4.5 & $11 \cdot 3$ & $10 \cdot 3$ & 9.7 & 11.9 & 9.2 & 9.0 & $5 \cdot 7$ & 5.0 \\
\hline Pro & 4.9 & 4.4 & $4 \cdot 3$ & 3.9 & 4.5 & 4.3 & 3.9 & 4.7 & \\
\hline Cys & $2 \cdot 1$ & 2.6 & $1 \cdot 3$ & 1.6 & 1.8 & 1.0 & 1.9 & 1.7 & \\
\hline Met & 2.4 & 0.7 & 0.5 & 0.7 & 0.3 & 0.8 & 0.7 & 1.6 & $4 \cdot 5 \|$ \\
\hline Trp & 1.5 & 1.0 & 0.2 & 1.1 & 0.1 & 0.6 & 0.2 & 1.0 & 1.5 \\
\hline
\end{tabular}

* For details of the fractions, see p. 444.

$\dagger$ A factor of 5.5 was used to convert $\mathrm{N}$ content to crude protein content for the lupinseed meal and its fractions while 6.25 was used for lactalbumin.

$\ddagger$ The amino acid profile was determined by acid hydrolysis $\left(6 \mathrm{M}-\mathrm{HCl}, 137^{\circ}, 18 \mathrm{~h}\right)$ followed by analysis on chromaspek. Five amino acids were determined by acid hydrolysis $\left(6 \mathrm{M}-\mathrm{HCl}, 137^{\circ}, 18 \mathrm{~h}\right)$ followed by ionexchange chromatography.

\& Coates et al. (1969).

I| Methionine+cystine. 
Table 3. Carbohydrate composition of Lupinus angustifolius-seed meal and its fractions $(\mathrm{g} / \mathrm{kg})^{*}$

\begin{tabular}{lcccccrr}
\hline & $\begin{array}{c}\text { Lupinseed } \\
\text { meal (LM) }\end{array}$ & LPAND & LPAD & LPADI & BUSOL & BUDI & LMR \\
\hline Monosaccharides & & & & & & & \\
Rhamnose & 5.0 & 2.0 & 1.0 & 1.0 & 9.0 & 4.0 & 9.0 \\
Fucose & 1.0 & trace $\dagger$ & trace $\dagger$ & trace $\dagger$ & 2.0 & 2.0 & 2.0 \\
Arabinose & 36.0 & 1.4 & 7.0 & 1.0 & 11.0 & 3.0 & 65.0 \\
Xylose & 24.0 & 2.0 & 5.0 & 2.0 & 7.0 & 2.0 & 53.0 \\
Mannose & 8.0 & 9.0 & 12.0 & 9.0 & 14.0 & 7.0 & 6.0 \\
Galactose & 132.0 & 20.0 & 31.0 & 7.0 & 37.0 & 8.0 & 214.0 \\
Glucose & 89.0 & 2.0 & 3.0 & 4.0 & 7.0 & 8.0 & 235.0 \\
Uronic acids & 32.0 & 2.0 & 5.0 & trace $\dagger$ & 19.0 & 6.0 & 62.0 \\
Total non-starch polysaccharides & 327.0 & 40.0 & 64.0 & 24.0 & 106.0 & 40.0 & 646.0 \\
Starch & 16.0 & 7.0 & - & 14.0 & 1.2 & 7.0 & 34.0 \\
\hline \hline
\end{tabular}

* For details of the fractionations and abbreviations used, see p. 444. Values for LM are given on an air-dry basis, those for the fractions are given on a dry-matter basis.

$\dagger$ Less than $0.5 \mathrm{~g} / \mathrm{kg}$.

$\ddagger$ Galacturonic acid.

Table 4. Comparison of haemagglutination activity of sweet lupin (Lupinus angustifolius)-seed extracts and freeze-dried fractions towards erythrocytes from rabbits, rats and hamsters*

\begin{tabular}{lccccc}
\hline \hline & $\begin{array}{c}\text { Crude protein } \\
(\mathrm{g} / \mathrm{kg} \text { seed })\end{array}$ & $\begin{array}{c}\text { Lectin } \\
(\mu \mathrm{g} / \mathrm{HU})\end{array}$ & \multicolumn{3}{c}{ Haemagglutinating activity (HU/g) } \\
\cline { 5 - 7 } Sample & & & Rabbit & Rat & Hamster \\
\hline Sweet lupin extract & 135 & 15 & nil & 9000 & ND \\
Kidney bean (Phaseolus vulgaris) & ND & 0.008 & ND & ND & ND \\
$\begin{array}{l}\text { var. Processor) lectin } \\
\text { Arcelin 2 lectin }\end{array}$ & ND & 4 & ND & ND & ND \\
LPAD $\dagger$ & 132 & 20 & ND & 123500 & 15000 \\
LPADI $\dagger$ & 36 & 40 & ND & 14000 & ND \\
LMR $\dagger$ & 36 & 40 & ND & 25000 & ND \\
\hline \hline
\end{tabular}

HU, units of haemagglutination activity, ND, not determined.

* For details of procedures, see pp. 444-445.

$\dagger$ For details of lupinseed fractions, see p. 444.

methionine content in the fractions ranged from 0.27 to 1.58 ; the half cystine content from 1.02 to 1.91 ; and the tryptophan content from 0.12 to $1.11 \mathrm{~g} / 16 \mathrm{~g} \mathrm{~N}$.

From restricted feeding trials (Table 6), animals fed on lupinseed unsupplemented (LMU) and fully supplemented (LMFS) with amino acids excreted significantly higher amounts of faeces (both dry and wet weights), with higher faecal $\mathbf{N}$, and had greater depletion of body lipids than the corresponding lactalbumin (LACT) control rats. The NPU values of the two diets were lower than that of LACT. All fractions (LPAND, LPAD, LPADI, BUSOL and BUDI) also had lower NPU values and caused greater depletion of body lipids than the control LACT. However, $\mathrm{N}$ digestibility was not affected. Feeding rats with diets in which protein had been almost removed by extraction (LMR) significantly increased faecal water and $\mathrm{N}$ contents. NPU and BV obtained with this diet were significantly greater than with other fractions tested. 
Table 5. Effectiveness of different sugars and glycoproteins at inhibiting the haemagglutination of trypsinized hamster cells caused by a dialysed aqueous extract from Lupinus angustifoliusseed meal (fraction LPAD)* $\dagger$

\begin{tabular}{lc}
\hline Inhibitor & Concentration giving $50 \%$ inhibition $(\mathrm{mg} / \mathrm{ml}) \ddagger$ \\
\hline$N$-acetyl glucosamine & $>25$ \\
$N$-acetyl galactosamine & $>25$ \\
D-Mannose & $>25$ \\
D-Galactose & $>25$ \\
L-Fucose & $>25$ \\
Fetuin & 0.625 \\
Thyroglobulin & $<0.20$ \\
Ovalbumin & $>2.5$ \\
Ovomucoid & 0.160 \\
\hline \hline
\end{tabular}

* For details of procedures, see p. 446.

$\dagger$ For details of fractionation, see Fig. 1.

$\ddagger$ Haemagglutinin concentration was kept constant, while inhibitors were serially diluted. The extent of agglutination was compared with that obtained with the lupin fraction in the absence of sugar or glycoprotein inhibitors.

The $\mathrm{N}$ balance experiment (Table 7) showed that rats fed on lupinseed meal and its fractions excreted three or four times more urea in the urine than the corresponding LACT control. Consequently, their NPU and BV values were lower. The nutritional performance of rats given LMR in the diet was similar to that of the LACT control.

Rats fed on the LACT diet from the balance trial had lower urea-N levels and higher body lipid contents. In contrast, rats fed on LMU and LMFS diets were depleted in body lipid.

\section{DISCUSSION}

The almost complete extraction of lupinseed proteins at $\mathrm{pH} 7.0(87.15 \%)$ obtained in our experiments (Fig. 1) was possibly helped by the comparatively low concentration of tannins in lupinseeds compared with that in soyabeans (Petterson et al. 1986) or faba beans (Vicia faba) (Marquardt, 1983). Rubio et al. (1992) found that $25 \%$ of the total Vicia faba seed protein was extracted at neutral $\mathrm{pH}$ and $25 \%$ remained with the hull, probably as a result of high tannin content. Therefore, the high recovery rate of protein from lupinseeds may be attributed to its solubility characteristics.

Haemagglutinating activity determination revealed that lupinseeds contained small amounts of non-toxic lectin, and compared with that of kidney-bean lectin it was 1875 times less reactive. This appears to be consistent with the findings of previous workers (Kim \& Madhusudhan, 1988).

Inclusion of L. angustifolius (sweet lupin)-seed meal at $100 \mathrm{~g} / \mathrm{kg}$ for young rats significantly impaired feed conversion efficiency and growth, and failed to satisfy all the nutritional requirements for growing rats. The low nutritional value of this seed meal was primarily due to the low NPU value (0.42). A similar poor utilization of sweet lupinseed meal has previously been reported (Yen et al. 1989; Rahman, 1995a,b; Rahman et al. 1996a). Since it was not clear which factors are responsible for this effect, the main fractions in the seed, namely proteins and carbohydrates were separated and tested on growing rats.

Protein-rich fractions obtained after cold water (LPAND, LPAD and LPADI) and phosphate-citrate buffer (BUSOL and BUDI) extraction significantly reduced NPU and 


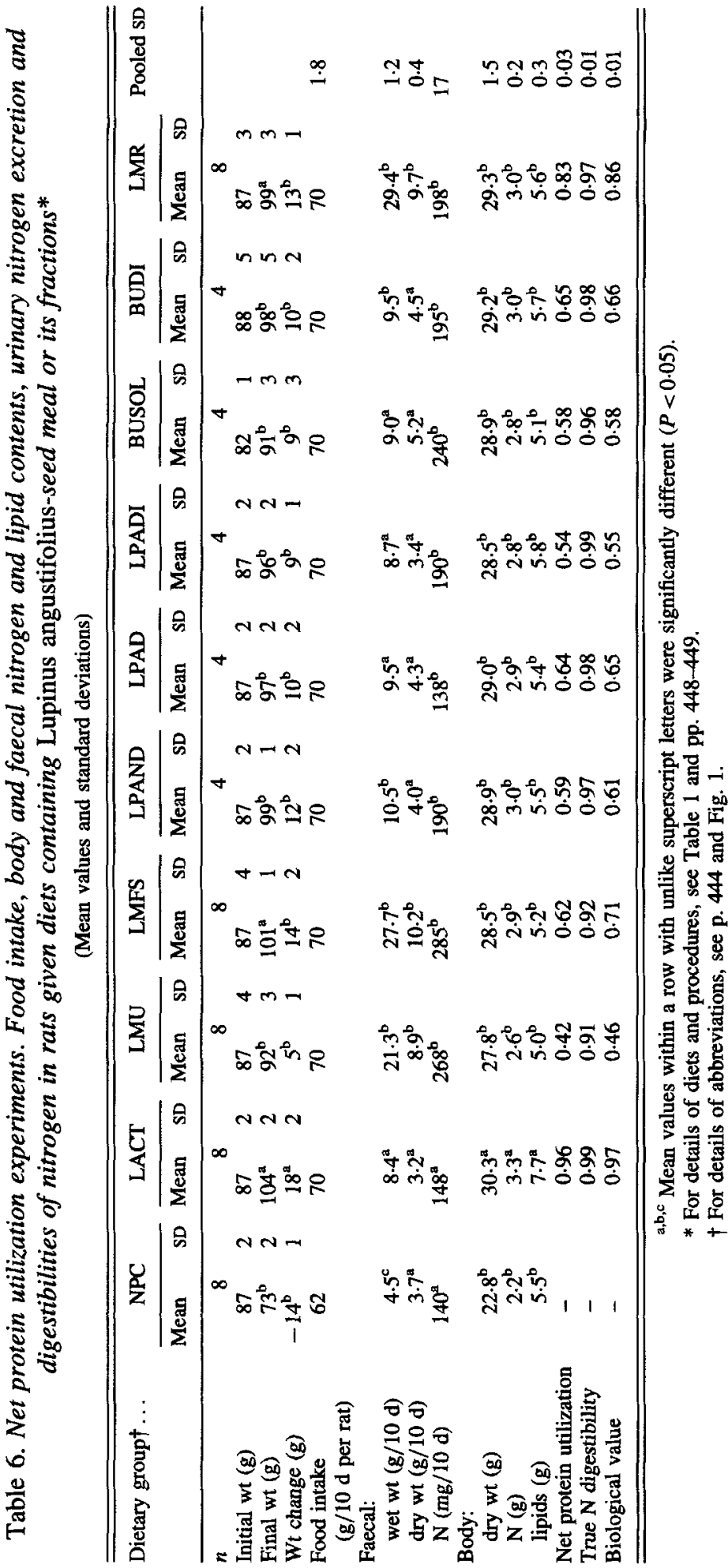




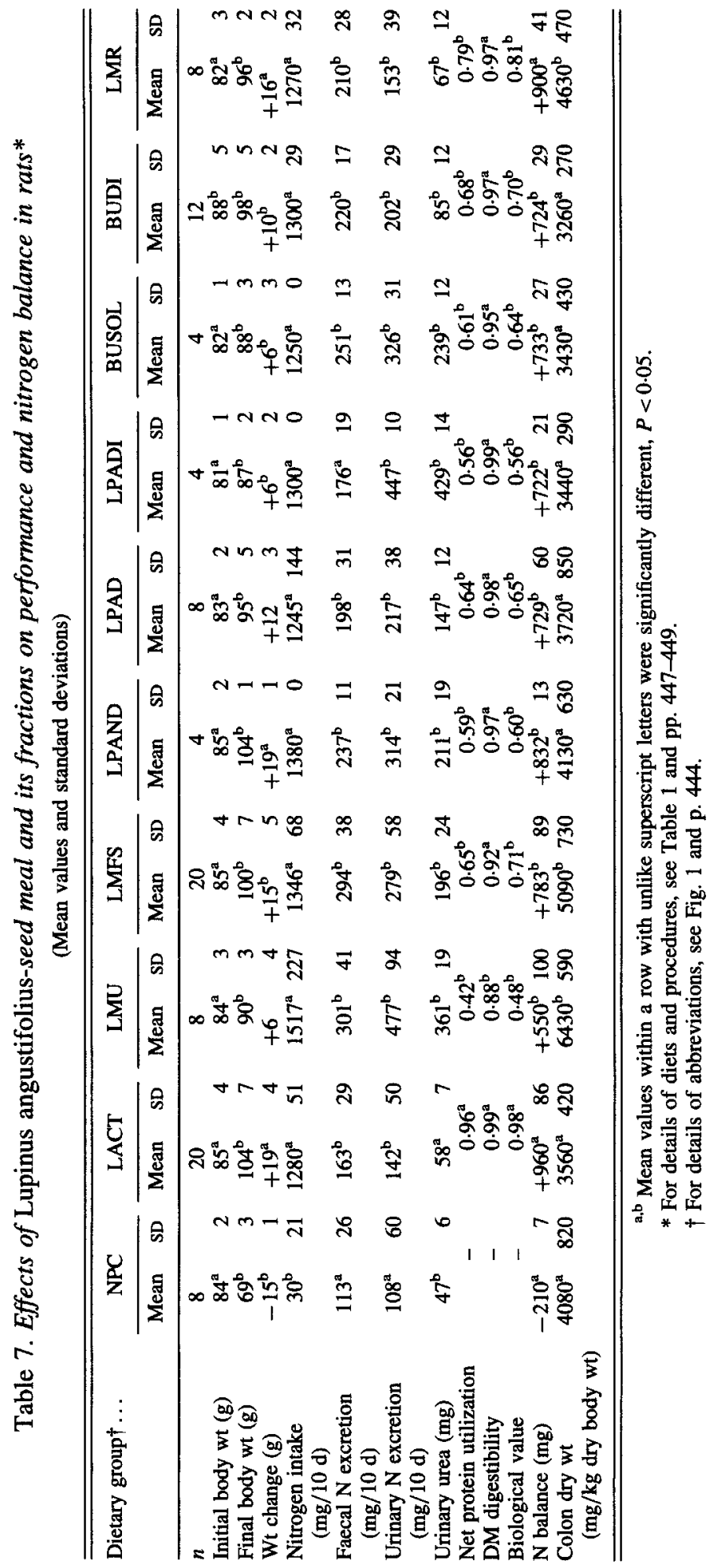


BV values of the proteins compared with those of the control based on lactalbumin protein. Replacement of $86 \mathrm{~g}$ of the $100 \mathrm{~g}$ seed protein by lactalbumin in the LMR diet significantly increased the NPU and BV of this fraction compared with those of the controls. However, this had no effect on true $\mathrm{N}$ digestibility, indicating that the reduced efficiency of protein utilization was due to increased excretion of $\mathbf{N}$ in the urine (mostly as urea) leading to lower accumulation of body $\mathbf{N}$, rather than $\mathbf{N}$ loss through the faeces. Despite calibration of the energy levels, rats fed on diets based on seed meal and fractions, including the LMR, accumulated less lipid than those obtained from the LACT control, suggesting that a higher lipid-energy metabolism may have partly compensated for the less efficient utilization of the protein obtained from $L$. angustifolius and its fractions.

The low NPU value of the seed meal was not clearly attributable to the lectins. It appeared from the inhibition tests carried out on protein fractions extracted at $\mathrm{pH} 7.0$ that lupin lectin activity could only be inhibited by thyroglobulin, suggesting that it can recognize complex oligosaccharide structures ( $\beta$-galactosyl group) which are normal structural components of eukaryotic cells (Pusztai, 1991). This could reflect the fact that lupin lectin may not attach to the rat enterocytes.

As the sweet lupin carbohydrate fraction contains a very high level of NSP which are poorly digestible, the effects of lupinseed meal on $\mathrm{N}$ utilization may be accounted for by the difference in the energy content of this diet compared with that of the lactalbumin control (LACT). Therefore, in the $\mathrm{N}$-balance experiments, the energy content was increased to compensate for this deficiency. The value for body lipid, however, was still found to be lower than the corresponding control value. Although it resulted in lower body lipid accumulation, the LMR diet was considered to be equal in energy to lupinseed meal. Thus, the effects of lupinseed proteins on $\mathrm{N}$ utilization should be comparable for the two diets. The small difference between the NPU values of 0.96 (LACT) and 0.83 (LMR) and the insignificant difference in $\mathrm{N}$ balance indicated that the observed difference in NPU between the LACT diet $(0.96)$ and the sweet lupinseed-meal diet $(0.62)$ could not have been due to the substitution of LMR for $112 \mathrm{~g}$ lactalbumin (equivalent to $86 \mathrm{~g}$ lactabumin protein), as this was the only difference between the two diets. Thus, we conclude that LMR (fibre fraction) caused malabsorption of the added lactalbumin. This supports the conclusion that the protein fraction of sweet lupinseed meal is not the only factor responsible for its low nutritional value (Rahman et al. 1996a).

As shown in Table 3, the insoluble carbohydrate fraction remaining after protein extraction (LMR), contained little starch, and most of it acted as a bulk in the lower intestine. These observations are supported by the highly significant dry weight increase in colon content in these rats as compared with that of the lactalbumin group (Table 7).

In conclusion, the main reason for the poor $\mathbf{N}$ utilization by rats fed on lupinseed meal and its fractions seems to be increased excretion of $\mathrm{N}$ in the urine, suggesting disturbances in systemic $\mathbf{N}$ metabolism. The proteins of sweet lupin are not only less nutritious than lactalbumin, but also appear to induce changes in body metabolism, for reasons that are as yet unknown. The nutritional value of sweet lupinseed proteins, therefore, should be examined carefully, especially in the light of the present experiments. In addition, the starch and NSP that constitute $467 \mathrm{~g} / \mathrm{kg}$ total DM of the seed appear to have deleterious effects on $\mathrm{N}$ utilization.

Thanks are due to the Government of the People's Republic of Bangladesh and the Board of Governors and Director of the Rowett Research Institute, Aberdeen, Scotland for providing financial support through ODA/The British Council and laboratory facilities. M.H.R. was on study leave from the Department of Pathology of Bangladesh Agricultural 
University. Grateful thanks are due to Dr Kathleen Margaret Botham, Department of Veterinary Basic Sciences, The Royal Veterinary College, University of London for her relentless support to M.H.R. during his stay in the UK and for critically reviewing this manuscript.

\section{REFERENCES}

Åman, P. \& Hesselman, K. (1984). Analysis of starch and other main constituents of cereal grains. Swedish Journal of Agricultural Research 14, 135-139.

Batterham, E. S. (1979). Lupinus albus cv. Ultra and Lupinus angustifolius cv. Unicrop as protein concentrates for growing pigs. Australian Journal of Agricultural Research 30, 369-375.

Batterham, E. S., Andersen, L. M., Burnham, B. V. \& Taylor, G. A. (1986). Effect of heat on the nutritional value of lupin (Lupinus angustifolius) seed meal for growing pigs. British Journal of Nutrition 55, 169-177.

Coates, M. E., O'Donoghue, P. N., Payne, P. R. \& Ward, R. J. (1969). Laboratory Animal Hand Books. 2. Dietary Standards for Laboratory Rats and Mice, p. 15. London: Laboratory Animals Ltd.

Dagnia, S. G., Petterson, D. S., Bell, R. R. \& Flanagan, F. V. (1992). Germination alters the chemical composition and protein quality of lupin seeds. Journal of the Science of Food and Agriculture 60, 419-423.

Davidson, J., Mathieson, J. \& Boyne, A. W. (1970). The use of automation in determining nitrogen by the Kjeldahl method, with final calculations by computer. Analyst 95, 181-193.

Egana, J. I., Uauy, R., Cassarola, X., Barrera, G. \& Yanez, E. (1992). Sweet lupin protein quality in young men. Journal of Nutrition 122, 2341-2347.

Englyst, H. N. \& Cummings, J. H. (1984). Simplified method for the measurement of total non-starch polysaccharides by gas-liquid chromatography of constituent sugars and alditol acetates. Analyst 109, 937 942.

Evans, A. J., Cheung, P. C.-K. \& Cheetham, W. H. (1993). The carbohydrate composition of cotyledons and hulls of Lupinus angustifolius from Western Australia. Journal of the Science of Food and Agriculture 63, 189-194.

Grant, G., Moore, L. J., McKenzie, N. H., Stewart, J. C. \& Pusztai, A. (1983). A survey of the nutritional and haemagglutination properties of legume seeds generally available in the UK. British Journal of Nutrition 50, 207-214.

Kim, C. S. \& Madhusudan, K. T. (1988). Haemagglutination and trypsin inhibitor activities of lupin seed (Lupinus angustifolius). Journal of Food Science 53, 1234-1235.

Laemmli, U. K. (1970). Cleavage of structural proteins during the assembly of the head of bacteriophage $T_{4}$. Nature 227, 680-685.

Mcllvaine, T. C. (1921). A buffer solution for colorimetric comparison. Joumal of Biological Chemistry 69, 183-186.

Marquardt, R. R. (1983). Antimetabolites in faba beans: their metabolic significance. FABIS News Letter 7, 1-4.

Miller, D. S. \& Bender, A. E. (1955). The determination of the net protein utilization of proteins by a shortened method. British Journal of Nutrition 9, 382-388.

Moore, S. (1963). On the determination of cystine as cystic acid. Journal of Biological Chemistry 238, 235-237.

Moore, S., Spackman, D. H. \& Stein, W. H. (1958). Chromatography of amino acids on sulphonated polystyrene resins. Analytical Chemistry 30, 1185-1190.

Mosse, J. (1990). Nitrogen to protein conversion factor for ten cereals and six legumes or oil seeds. A reappraisal of its definition and determination. Variation according to species and to seed protein content. Journal of Agricultural and Food Chemistry 38, 18-24.

Murphy, S. R., McNiven, M. A., MacLeod, J. A. \& Halliday, L. J. (1993). Grass and lupin silage in rations for beef steers supplemented with barley or potatoes. Animal Feed Science and Technology 40, 273-283.

Palmer, R., McIntosh, A. \& Pusztai, A. (1973). The nutritional evaluation of kidney bean (Phaseolus vulgaris). The effect on nutritional value of seed germination and changes in trypsin inhibitor content. Journal of the Science of Food and Agriculture 24, 937-944.

Petterson, D. S., Allen, D. G., Greirson, B. N., Hancock, G. R., Harris, D. J. \& Legge, F. M. (1986). The suitability of Lupinus angustifolius seed for human consumption. Proceedings of the Nutrition Society of Australia 11, 118.

Pusztai, A. (1991). Plant Lectins, p. 28. Cambridge: Cambridge University Press.

Pusztai, A., Clarke, E. M. W., Grant, G. \& King, T. P. (1981). The toxicity of Phaseolus vulgaris lectins. Nitrogen balance and immunochemical studies. Joumal of the Science of Food and Agriculture 32, 10371046.

Pusztai, A., Clarke, E. M. W. \& King, T. P. (1979). The nutritional toxicity of Phaseolus vulgaris lectins. Proceedings of the Nutrition Society 38, 115-120.

Rahman, M. H. (1994). Chemical and nutritional evaluation of Lupinus angustifolius L. (sweet lupin) seed proteins and its fractions on general metabolism of monogastric animals. PhD Thesis, University of Aberdeen. 
Rahman, M. H. (1995a). Protein quality of sweet lupin and its effects on certain haematobiochemical constituents in growing rats. Bangladesh Veterinary Journal 28, 57-62.

Rahman, M. H. (1995b). Nutritional response of growing rats to sweet lupin ( $L$. angustifolius) and sweet lupin fractions. In Proceedings of 2nd European Conference on Grain Legumes-1995, pp. 296-297. Copenhagen: AEP (European Association for Grain Legume Research).

Rahman, M. H., Hossain, M. I. \& Moslehuddin (1996a). Faecal composition and nitrogen excretion of rats fed on diets containing sweet lupin (Lupinus angustifolius L.) or its fractions. Joumal of the Science of Food and Agriculture 70, 468-474.

Rahman, M. H., Hossain, M. I. \& Moslehuddin (1996b). Mineral balance of rats fed on diets containing sweet lupin (Lupinus angustifolius L.) or its fractions. Animal Feed Science and Technology (In the Press).

Rubio, L. A., Grant, G., Bardocz, S., Dewey, P. \& Pusztai, A. (1992). Mineral excretion of rats fed on diets containing faba beans (Vicia faba L.) or faba bean fractions. British Joumal of Nutrition 67, $295-302$.

Yen, P. Y., Grant, G., Fuller, M. F. \& Pusztai, A. (1989). Nutritional evaluation of sweet lupinseed (Lupinus angustifolius). Proceedings of the Nutrition Society 49, 145A. 